\title{
FROM MILITANTS TO SECRET AGENTS: UKRAINIAN COMMUNISTS UNDER GENERAL DENIKIN*
}

\author{
Éric Aunoble \\ University of Geneva, \\ Geneva, Switzerland
}

During the Civil War, the Communist Party and its activists had to constantly adapt to ever-changing situations. This paper aims to study their reaction in Ukraine in 1919 after Denikin took control of the country. It will focus on the 800 activists sent behind enemy lines from July to November 1919. Using the paperwork of special bodies created by the Central Committee (CC) of the Communist Party (Bolshevik) of Ukraine $(\mathrm{CP}(\mathrm{b}) \mathrm{U})$ to tackle this task (Zafrontbyuro - rearguard bureau; Voenotdel - military department; Otdel Svjazi - communications department), the article will first question the way underground activists were selected. Second, it will highlight how missions behind enemy lines were designed and organized. Third, it will consider the missions themselves and the hardships endured once activists reached Denikin-controlled territory. Fourth, one has to wonder what activists tried to do, questioning what they thought about their dangerous job and what their missions effectively brought to the Bolsheviks. This will help us understand how the Civil War was indeed a "formative experience" (in Sheila Fitzpatrick's words) for the communists, shaping their worldview and behavior.

Keywords: Civil War, Ukraine, 1919, General Denikin, Communist Party, White Terror, repression, Bolshevik underground

Во время Гражданской войны Коммунистической партии и ее активистам приходилось постоянно приспосабливаться к быстро меняющимся обстоятельствам. Целью настоящей статьи является изучение их реакции на захват власти Деникиным на Украине в 1919 г. Речь идет о 800 активистах, которые были отправлены в тыл врага с июля по ноябрь 1919 г. На основе архивных материалов специальных органов (Зафронтбюро, Военотдела, Отдела связи), созданных при ЦК КП(б) Украины, изучается вопрос о том, как отбирались кандидаты в подпольщики и каким образом организовывались миссии в стане врага. Статья описывает сами миссии, трудности и риски, с которыми сталкивались активисты, оказавшись на контролиру-

* Citation: Aunoble, É. (2021). From Militants to Secret Agents: Ukrainian Communists under General Denikin. In Quaestio Rossica. Vol. 9, № 1. P.91-108. DOI 10.15826/qr.2021.1.567.

Цитирование: Aunoble É. From Militants to Secret Agents: Ukrainian Communists under General Denikin // Quaestio Rossica. Vol. 9. 2021. № 1. P. 91-108. DOI 10.15826/qr.2021.1.567.

(c) Aunoble É., 2021

Quaestio Rossica • Vol. 9 • 2021 • № 1, p. 91-108 
емой Деникиным территории, их мнения о своей задаче, а также то, какую пользу из их действий извлекали большевики. Все вышеизложенное позволяет понять, что делало Гражданскую войну подлинным «формирующим опытом» (по словам Шейлы Фицпатрик) для коммунистов, определяющим их мировоззрение и поведение.

Ключевые слова: Гражданская война, Украина, 1919, Деникин, Коммунистическая партия, белый террор, репрессии, большевистское подполье

The deeds of the communists were beyond history according to Stalin, who stated "that the Bolsheviks remind us of the hero of Greek mythology, Antæus" [History of the Communist Party of the Soviet Union (Bolsheviks), p. 362-363]. From an opposite point of view, Adam B. Ulam agreed that "the story of the Bolsheviks... is one of drama and success unparalleled in modern history", although it bore "the seeds of future totalitarianism" [Ulam, p. VII]. A view from the periphery confirms that Bolshevism's rise to power meant the end of freedom for the people. As Ivan Maistrenko puts it, "the history of the Communist Party of Ukraine is also the history of Ukraine after it was conquered by Soviet Russia" [Майстренко, c. 5]. Since "success" turned into failure in 1991, Russian and Ukrainian archive-based studies alike have focused on the way Bolsheviks constituted a new elite taking control over the country [Фролов], the nomenklatura [Дорошко], which had common traits with the medieval "brotherhood of the sword" [Павлюченков].

Still, few scholars have tackled a key issue: how a militant group that had been a part of the "liberation movement" against tsarist autocracy and relied on radicalized workers became a ruling bureaucracy. Alexander Rabinowitch has traced this process in Petrograd from early 1917 to late 1918 [Rabinowitch, 1968; Rabinowitch, 1976; Rabinowitch, 2007]. At this time, the Civil War had begun but the worst was yet to come, as its flames burnt across all the former empire for two more years. This period was a source of multiple experiences for activists. An early Bolshevik did not live through these events in the same way as someone who had joined the Party after October, just as a militant from Petrograd or Moscow, the heart of Soviet Russia, was surely in a different position from a communist in Ukraine, where "Soviet power" was not firmly established until 1920. People and party structures had to constantly adapt to ever-changing situations, making their ideas and practices evolve rapidly several times.

We can observe this phenomenon in Ukraine in 1919. Ukrainian Bolsheviks were so self-confident when they seized power over eastern Ukraine in late 1918 - early 1919 that they implemented very radical policies, particularly in the countryside. After a few months of Red rule, they suddenly realized that they were short of support, especially among the peasantry. Thanks to this, the White Voluntary Army of General Denikin took over eastern Ukraine in the late spring of 1919 and started moving north toward Moscow. This was the beginning of the most difficult period for Soviet power during the Civil War, when the Sovdepiya, under the threat of 
several enemies, was nearly reduced to the territory of ancient Muscovy. The occupation of Ukraine by the White Army was also a deep shock for the Ukrainian Bolsheviks, who fell from the heights of power to the status of persecuted outlaws.

This paper aims to study the reaction in Ukraine of the apparatus of the Communist Party (Bolshevik) of Ukraine $(\mathrm{CP}(\mathrm{b}) \mathrm{U})$ and its activists to this distressing situation. Three special bodies designed to tackle were created by

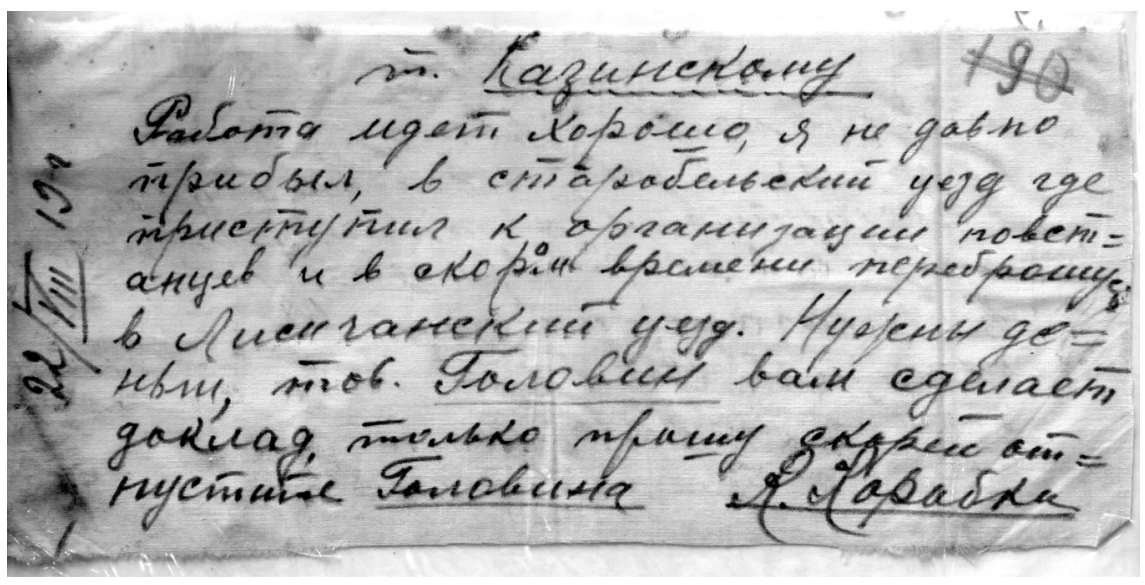

1. Report about the organisation of partisan units by Korobkin in the Donbass uyezds of Starobel'sk and Lisichansk in August 1919 // TsDAGOU. Stock 1. List 18. Dos. 33. F. 10

the Central Committee (CC) of the CP(b)U: the Zafrontbyuro (literally "beyond-the-front-line bureau" or "rearguard bureau" in Yaroslav Bilinsly's words [Hunczak, p. 121]), the Voenotdel (military department) and the Otdel Svjazi (communications department) organized a web of underground militants acting under Denikin. Among the paperwork these departments produced [ЦДАГОУ. Ф. 1. Оп. 18], one can find some impressive tables regarding 800 activists sent behind enemy lines from July to November 1919. The reports kept about their activity tell a slightly different story: every mission could fail, as an activist could fall ill with typhus or be arrested and shot on the spot. In the 1920s and early 1930s, when the new elite could still publicly remember its glorious past, some of this material was published in the Ukrainian Istpart ${ }^{1}$ journal, Letopis Revolyutsii. After this, one had to wait until the mid-1960s to read the first scholarly study on the topic. Written in the Soviet style, it had to prove that the Zafrontbyuro "followed Lenin's advice" and "created the necessary conditions for the activity of underground activists and partisan units." Nonetheless, it is a rather reliable factual account, as it tells us much about the roles of Vladimir Zatonsky and Stanislav Kossior, who were rehabilitated in the late 1950s after having been eliminated as "enemies of the Party.

${ }^{1}$ Istpart: Commission for the History of the October Revolution and of the Communist 


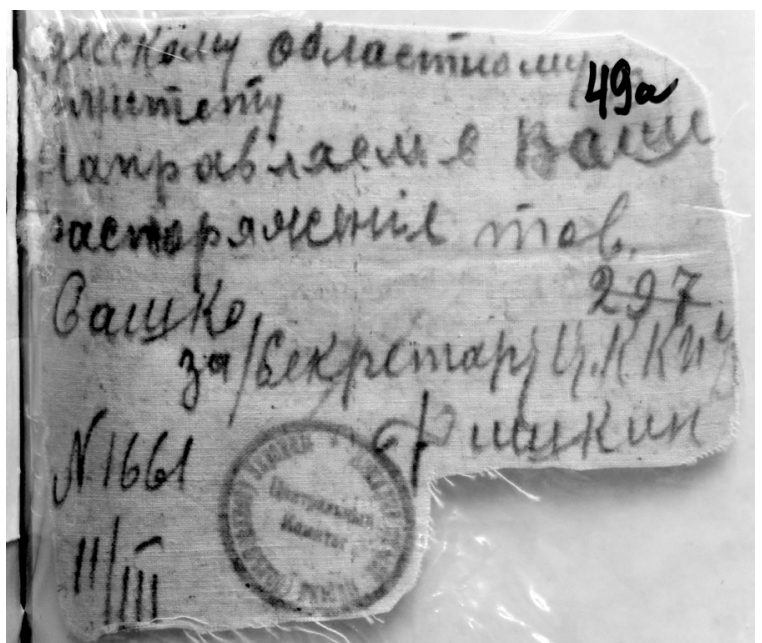

2. Mandate of comrade Sashko sent by the CC of the $\mathrm{CP}(\mathrm{b}) \mathrm{U}$ to the Odessa underground Party Committee // TsDAGOU. Stock 1. List 18. Dos. 5. F. 49A

people" in 1936-1938

[Случевская, с. 5, 305].

The emphasis of this paper will focus on activists' experiences. Thanks to both published and previously unreleased material, it will first question the way underground activists were selected. Second, it will highlight how missions behind enemy lines were designed and organized. Third, it will consider the missions themselves and the hardships endured once activists reached Denikin-controlled territory. Fourth, one has to wonder what activists tried to do, questioning what they thought about their dangerous job and what their missions effectively brought to the Bolsheviks. This will help us understand how the Civil War was indeed a "formative experience" (in Sheila Fitzpatrick's words) for the communists, shaping their worldview and behavior.

\section{The Selection of Underground Activists}

The defeat of the Reds in the spring and summer of 1919 was twofold. Eastern Ukraine was under threat from Denikin from April, when the Voluntary Army started to conquer the Donbass, until late June, as White troops took over Khar'kov (Kharkiv) and Yekaterinoslav (Dnipro). In Central Ukraine, the Bolsheviks were forced out of Kiev (Kyiv) ${ }^{2}$ in the closing days of August: Petlyuras's soldiers, coming from the west, entered the city the same day as Denikin's, coming from the east. When reading Soviet historiography, one might think that the Reds retreated in an orderly fashion while preparing a counteroffensive. Members of the Communist Party were mobilized by decree into the Red Army or local armed units as soon as the White troops approached the Donbass and then the Kiev region [Случевская, с. 14-17, 32-34]. Other sources show a rather different picture, one of panic and escape: "The people rushing north cannot be described as a united, structured or organized whole. It was a ramshackle collection of people. Some communists' fathers and mothers... some com-

\footnotetext{
${ }^{2}$ The contemporary Ukrainian names are mentioned in brackets when employed for the first time. Otherwise, the 1919 Russian form is used in this paper (as it is done in primary sources).
} 
munards... various adventurers were also fleeing. In a word, all sorts of people were fleeing to the north, in those stifling days of the terrible year nineteen" [Хвильовий, с. 398].

In such an atmosphere, only two local Bolshevik organizations in the whole of Ukraine were able to set up in advance a web of underground activists who would stay when the area was occupied by the enemy: in Kremenchug (Kremenchuk) and Odessa (Odesa), which were conquered by the Whites in August [КП(б)У за Денікінщини, 1929, № 5-6, с. 290; 1930, № 1, c. 226-233]. Earlier, such local initiatives were impossible. This highlighted the need for central bodies created by the CC that could coordinate underground activity. The Zafrontbyuro was established on 30 June, a few days earlier than the other departments. They had to call for volunteers, who were more or less recommended by local party committees or high party officials. As a consequence, "not all of the enrolled staff members fit their task and a lot of them are completely casual towards the revolution" [ЦДАГОУ. Ф. 1. Оп. 18. Д. 40, Л. 11, 33-37 (lists of volunteers)].

Besides the lack of preparation, random recruitment also resulted from a situation which was awkward in itself. As an activist sent to $\mathrm{Ne}$ zhin (Nizhyn) summed it up: "Those who were left by the [local] party committee to go underground could not show up as everybody knew them as communists". In contrast, an undercover Bolshevik envoy "did not even know where the party committee was for all the time of his stay in Nezhin" [ЦДАГОУ. Ф. 1. Оп. 18. Д. 16. Л. 93]. In other words, the choice was either to use activists with local connections who risked being arrested or outsiders who would be safer but unable to act. In Odessa, "it [was] decided in advance that all communists who were not under physical threat, that is those who would not be prosecuted, [would be] strongly recommended to stay" which meant especially that "women [were] strongly recommended to stay" [КП(б)У за денікінщини, 1930, № 1, с. 230]. Although they seem to have been a minority among the underground activists ${ }^{3}$, the participation of women is indeed noteworthy, as they accomplished missions just as risky as those of their male counterparts.

Other subaltern categories were also especially committed to undermining Denikin's victory. Dedicated party organizations like the Young Communists' League and the head committee of the Jewish Communist Union encouraged them to do so. The latter provided the CC of the $\mathrm{CP}(\mathrm{b}) \mathrm{U}$ with the names of 13 volunteers from among its senior activists. [ЦДАГОУ. Ф. 1. Оп. 18. Д. 5, Л. 29, 33]. When we note in another document that one Jewish activist's monicker was Spinoza, one can imagine the ideals that moti-

\footnotetext{
${ }^{3}$ For instance, among the 49 names authoring reports, there are four feminine ones [ЦДАГОУ. Ф. 1. Оп. 18. Д. 16]. Still, it is difficult to be sure of the gender of the activists. Statistical records mention the number of envoys per region and city, but do not say a word about people's profiles. In their turn, the reports relate about missions and how they were completed and give only scarce information about the activists themselves. One might guess the agent's gender whenever it is mentioned as being relevant to the fact or by his/her name, although monikers can be misleading.
} 
vated them to risk their lives [ЦДАГОУ. Ф. 1. Оп. 18. Д. 16. Л. 17]. However, the dedication of Jews and youngsters eventually proved to be a problem for underground organizers. As one stated, central party bodies "left [behind enemy lines] thousands of little boys and girls who did not at all suit the job and impeded it... they mainly left Jew[ish] com[rades], who are just not suitable for Ukraine in this atmosphere of pogroms. $<\ldots>$ Jews are thrown out of railway coaches or just killed" [ЦДАГОУ. Ф. 1. Оп. 18. Д. 5. Л. 11в; КП(б)У за Денікінщини, с. 281]. The peak of anti-Semitic atrocities was indeed reached in Ukraine in the summer of 1919 [Abramson, p. 114]. On the one hand, anti-Semitism was strong among peasants who feared that "behind Soviet power Jews will stand” [ЦДАГОУ. Ф. 1. Оп. 18. Д. 20. Л. 8-9 об.]. On the other, the Whites treated their Red prisoners along political, national, and racial criteria: "Communists are shot on the spot. Commanders are beaten or killed. The same goes for Jews, Latvians, and Chinese. $<\ldots>$ First of all, the Cossacks demanded 'Yid nurses' be handed over” [ЦДАГОУ. Ф. 1. Оп. 18. Д. 5. Л. 16]. As a consequence, one organizer bluntly expressed "the urgent need for Russian (only Russian) activists" to be sent.

In fact, they had to be satisfied with the people on hand, be they "deserters who did not want to follow the Red Army's retreat and who remained as parasites" or "devoted and honest revolutionaries" [КП(б)У за Денікінщини, 1929 , c. 295]. Besides moral qualities, skills and efficiency could be victims to the loose recruitment structure. An agent shot another comrade by accident during a secret meeting in Yekaterinoslav, perhaps because they were not used to weapons [Там же, с. 290]. Amateurism could have less tragic and even funny consequences. In late summer 1919, a group of activists from Bakhmut had the wonderful idea of setting up a peculiar form of underground activity: four of them joined a Ukrainian touring theatre company in order to cross the frontline and then travel freely in the White territory. Eventually, after various setbacks (including learning how to act), their plan failed and they had to wait for the Red Army's decisive offensive in December to go back to Ukraine [ЦДАГОУ. Ф. 1. Оп. 18. Д. 20. Л. 14-15]. Among the mishaps that delayed them was also the tardiness of some party structures when it came to helping volunteers, which was sharply criticized by other activists as early as July [ЦДАГОУ. Ф. 1. Оп. 18. Д. 47. Л. 1].

\section{The Organization of Underground Missions}

The impression of negligence is confirmed when considering the organization of missions: "The CC did not have a defined point of view concerning the underground work under Denikin. $<\ldots>$ They gave certain instructions to some envoys and different ones to other envoys, and for us, remaining in the deep rear... it was difficult to choose an option" [ЦДАГОУ. Ф 1. Оп. 18. Д. 16. Л. 18-19; КП(б)У и Деникинщина, с. 33-34]. Furthermore, "there was no general plan in order to build underground organizations" and "throughout the four months of reaction, all in all only two directives [were sent] from the center, and only very recently" [КП(б)У за Денікінщини, 1929, c. 303, 307]. 
Apart from technical and political matters, which will be dealt with later, disorganization appears to have been the result of poor coordination among the many different organizations tackling the issue: "The several different existing Zafrontbyuros and committees to transfer people do not do anything good" [КП(б)У за Денікінщини, 1929, с. 304]. If we try to list the different bodies dealing with underground activists behind enemy lines, we find that the Central Committee of the $\mathrm{CP}(\mathrm{b}) \mathrm{U}$ alone established the organization bureau (orgbyuro), the Zafrontbyuro, the military department (Voenotdel), and the latter's communications department (Otdel svyazi). The Voenotdel, which was specialized in setting up insurgent units, and the Zafrontbyuro were supposed to work together under the supervision of the Orgbyuro [ЦДАГОУ. Ф. 1. Оп. 18. Д. 40. Л. 11]. The Otdel svyazi was meant to keep in touch with the HQs of insurgent units in order to share political information and guidance, as well as provide material support [Там же. Л. 16]. Alongside the inner bodies of the $\mathrm{CP}(\mathrm{b}) \mathrm{U}$ 's CC, military intelligence (Registrup RVSR) was also interested in collecting information about White-occupied territories; however, it was not connected with the $\mathrm{CP}(\mathrm{b}) \mathrm{U}$, but rather with the foreign bureaus of the Russian Communist Party (Bolsheviks) [ЦДАГОУ. Ф. 1. Оп. 18. Д. 5. Л. 25]. This reminds us of the special status of the $\mathrm{CP}(\mathrm{b}) \mathrm{U}$ as both a self-standing party and a branch of the $\mathrm{RCP}(\mathrm{b})$. This means that a communist from Ukraine could switch from an organ of the $\mathrm{CP}(\mathrm{b}) \mathrm{U}$ to a Ukrainian body of the RCP(b) if the former's policy did not please him [ЦДАГОУ. Ф. 1. Оп. 18. Д. 16. Л. 59 об.]. Moreover, as the frontline moved westward in late 1919, party structures, whatever they were, had to coordinate with the Red Army [ЦДАГОУ. Ф. 1. Оп. 18. Д. 5. Л. 26; КП(б)У за Денікінщини, 1929, с. 273-274].

What can be described as chaos in the decision-making is also typical of what Marc Ferro has called the "polymorphous power" and "institutional polymorphism" that left an imprint on the Soviet state from its revolutionary origins [Ferro]. And one must not forget that this was an adaptation to real difficulties. As the frontline moved throughout the second half of 1919, so too did the Zafrontbyuro, from Kiev to Kremenchug, Bryansk, Moscow and eventually Serpukhov [Мишкис, c. 248-249; КП(б)У за Денікінщини, 1929, с. 269]. Activists at its disposal were sought to enter local party cells before being sent behind enemy lines: this added to the institutional complexity and made untimely individual initiatives possible [ЦДАГОУ. Ф. 1. Оп. 18. Д. 16. Л. 57 об.; Ф. 1. Оп. 18. Д. 20. Л. 14; КП(б)У за Денікінщини, 1929, с. 267].

All this was a consequence of the specific type of war going on. Andrei Bubnov, a high-ranking Ukrainian Bolshevik, was aware of this: "under today's circumstances, work behind the frontline [...must] combine the methods of 'great' and 'little' wars" [ЦДАГОУ. Ф. 1. Оп. 18. Д. 42. Л. 58]. Thus, three types of missions were envisaged for Bolsheviks sent behind enemy lines. First, intelligence missions would gather information of a military and, above all, political character through envoy observations and col- 
lected White newspapers ${ }^{4}$. Second, organizational missions would aim at connecting with existing underground Bolshevik groups or setting up and strengthening such groups. Third, military missions would create and coordinate partisan units. There were two categories of envoys, "senior officials" (700 otvetstvennye rabotniki) with political responsibilities and "technical workers" (100 tekhnicheskie rabotniki, mainly printers or military specialists) [ЦДАГОУ. Ф. 1. Оп. 18. Д. 5, Л. 43-45; Мишкис, с. 250].

The different bodies that organized the missions prepared lists and tables in order to manage the envoys, but their main logistical task was to provide them with money, mandates, false documents, and the addresses of yavki (hideouts). Money was needed to fund underground activity, but it made the envoys vulnerable to theft and ransom [ЦДАГОУ. Ф. 1. Оп. 18. Д. 5. Л. 51a, 516; Ф. 1. Оп. 18. Д. 16. Л. 42]. Mandates, which had to be hidden until being exhibited as credentials to local comrades, were usually printed on fabric

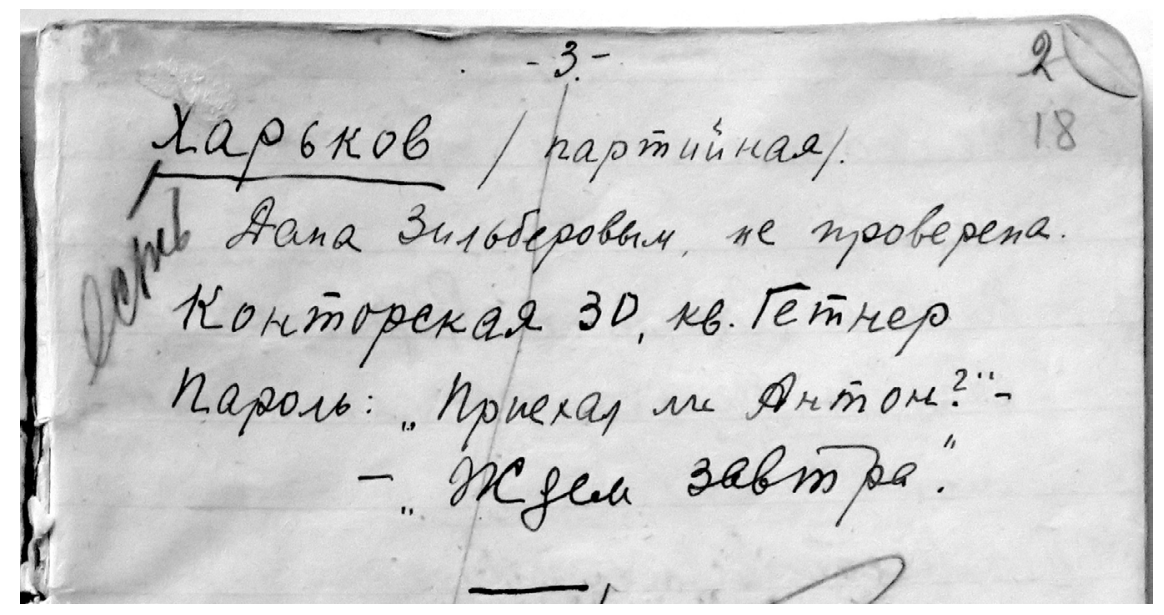

3. A yavka (safe house) in Kharkov and its password // TsDAGOU. Stock 1. List 18. Dos. 41. F. 18

and sewn into the linings of garments. False documents were also a sensitive issue, as envoys relied on them when they were checked by the Strazha. Unfortunately, these were weak spots in the Central Committee's technical organization: "three-foot-long mandates" were not suitable for secrecy, and "more than one comrade was shot because of 'little inaccuracies' in passports", such as a non-existent address or an implausible date of issue [ЦДАГОУ. Ф. 1. Оп. 18. Д. 16. Л. 19; КП(б)У и Деникинщина, с. 34].

Many of these complaints are known thanks to envoys' reports. Before the reconquest of Ukraine, these reports were the minutes of formal debrief-

\footnotetext{
${ }^{4}$ A man caught by Denikin's police, the Strazha, with a collection of newspapers would be suspected of being a Bolshevik; and if caught by the Reds, they would consider him a white agent [КП(б)У за Денікінщини, 1929, с. 268-269; ЦДАГОУ. Ф. 1. Оп. 18. Д. 16. Л. 31].
} 
ings held upon the envoy's return: a secretary wrote down the contents of the interview and the envoy signed. Those who were still in Ukraine when the Red Army came wrote their reports after the victory. Both these sources offer a very colorful picture of the missions completed by the activists.

\section{Underground Missions under Denikin}

Activists faced a very ambitious agenda, but most of them succeeded regardless of the difficulties. Among the reports of intelligence and organizational missions we examined for this study, a quarter failed ${ }^{5}$. Some activists were not able to pass through the frontline. Others were arrested as soon as they arrived in the White territory or became seriously ill with influenza or typhus. In some cases, envoys could not make contact with anyone during their time behind enemy lines [ЦДАГОУ. Ф. 1. Оп. 18. Д. 16. 20, 21, 42]. In any case, three-quarters of the reports tell how activists succeeded and embarked on what looked like very adventurous journeys. For instance, one traveled from Kiev to Krivoy Rog (Kryvyi Rih), Yekaterinoslav, Khar'kov, Kiev, Glukhov (Hlukhiv) and Briansk (1800 km), while another left from Gomel to Poltava, Yuzovka (Donetsk), Armavir, Rostov, Lozovaya, Kharkov, Kursk and L'gov (2600 km), all in enemy territory except for the cities of departure and arrival. As undercover agents, they had to play roles: a railway mechanic or, more ironically, a bagger (meshochnik) or speculator (considered the most secure) [ЦДАГОУ. Ф. 1. Оп. 18. Д. 16. Л. 64, 68, 73].

The main risk was being arrested, and the reports give an interesting insight into a much-discussed topic, the counter-revolutionary repression under Denikin. The first difficult step was to cross the frontline, where one could be shot if one's papers were proven false or if one was caught by chance [ЦДАГОУ. Ф. 1. Оп. 18. Д. 21. Л. 1; Ф. 1. Оп. 18. Д. 42. Л. 4]. Nevertheless, the frontline was not an insurmountable barrier: the most dangerous places for underground Bolsheviks were trains and railway stations, especially due to the aforementioned persecution of "Jewish-looking" activists. This sounds quite logical for various reasons. To the astonishment of underground Bolsheviks, Denikin did not leave that many soldiers or policemen in the rear [ЦДАГОУ. Ф. 1. Оп. 18. Д. 5. Л. 2-5, 11; Ф. 1. Оп. 18. Д. 16. Л. 18-19]. Coaches and railway premises were much easier places to control and lockdown. Furthermore, all dubious people, thieves, smugglers, and revolutionaries alike, would be more likely to travel than the average obyvatel' (man on the street). When the latter went by train, they would be eager to report suspicious people to the railway guard, as they feared for their own life and security. As all society was under the stress of civil war, mutual fear and antagonism contributed to a pogrom-like atmosphere where people resorted to violence against "Jewish - looking" individuals as an outlet. Last but not least, railway guards arrested people randomly in order to ask them for bribes.

\footnotetext{
${ }^{5}$ As dead people do not write accounts, reports of failures do not include the shooting of envoys.
} 
Once in operation, an underground activist could also be arrested when the enemy carried out roundups, especially after a place had been conquered [КП(б)У за Денікінщини, 1929, с. 292]. Even the Makhnovists did so against communists [ЦДАГОУ. Ф. 1. Оп. 18. Д. 16. Л. 40]. Of course, the most dangerous moment was when taking action, be it leafleting or trying to steal money for the cause [КП(б)У за Денікінщини, 1929, с. 297-298]. Equally, Bolsheviks could also be arrested as soon as they were recognized as such on the street. This could happen by chance [ЦДАГОУ. Ф. 1. Оп. 18. Д. 16. Л. 47 $]^{6}$, but underground activists were particularly vulnerable to provocateurs. The latter were mainly former supporters of the Soviet regime who had changed sides (including Red Army officers and Cheka officials) [КП(б)У за Денікінщини, 1929, с. 295, 301; ЦДАГОУ. Ф. 1. Оп. 18. Д. 16. Л. 16-16 об., 63, 97 об.]. Communists tried to counteract this by setting up locally some counter-counter-intelligence service through their underground organizations [КП(б)У за Денікінщини, 1929, с. 289]. Later, after the Red victory, identified provocateurs were listed, seemingly to be searched and prosecuted [ЦДАГОУ. Ф. 1. Оп. 18. Д. 5. Л. 48].

Once arrested, a communist risked being beaten up and being shot on the spot. One activist recalled: "I saw how those who had arrested my comrade led him across the railway line, from where one shot of a revolver was heard. I do not know about his further fate” [ЦДАГОУ. Ф. 1. Оп. 18. Д. 16. Л. 65]. If not executed right away, a Bolshevik could be confronted with quite varied situations after having been arrested. One saved his life by pretending he was a criminal and not a revolutionary [КП(б)У за Денікінщини, 1929, c. 297]. When identified as a communist, one could be "beastly tortured" in order to make one confess and give away one's comrades. Nonetheless, there was a fairly simple and reliable means to save jailed comrades: to buy their lives and freedom by giving bribes to Denikin's policemen or prison wardens. This could be done by the inmate himself if he had enough money. It could also be negotiated by a dedicated branch of the underground Bolshevik organization in town, the "Political Red Cross" [КП(б)У за Денікінщини, 1929 , c. $285-286,296 ; 1930$, № 1, c. 238]. Hence, arrested Reds were considered "money bags" [ЦДАГОУ. Ф. 1. Оп. 18. Д. 42. Л. 46]: the price for freedom ranged from 2000 to 40000 rubles according to different sources. Thus, underground Bolshevik groups faced financial pressure: "Due to the lack of financial resources... comrades surely died; with money, we could have bought them back" [КП(б)У за Денікінщини, 1929, с. 297].

The possibility of buying back arrested revolutionaries shows just how loose discipline and moral standards were among the White security forces. It also suggests paradoxically that Bolshevik activists had some individual value that was recognized by their enemies, albeit in a monetary way. This contrasts sharply with other forms of "White Terror", which was perpetrat-

${ }^{6}$ Or due to mishaps of the Reds: Denikin's intelligence found lists of Soviet officials, which were published in the press: and arrests were ordered on this basis [КП(б)У за Денікінщини, 1929, с. 302]. 
ed en masse against Red Army prisoners, petty collaborators of the defeated Soviet regime or rioting villagers ${ }^{7}$. The sense of one's worth can also be felt in the envoys' reports when they recall their adventurous deeds and heroic gestures. One envoy who was about to be searched shot the enemy agent with the latter's own Browning [ЦДАГОУ. Ф. 1. Оп. 18. Д. 20. Л. 6 об.]. Another, who was imprisoned, managed to save a fellow inmate's life by arguing that she was a very young girl and the daughter of a priest ${ }^{8}$. He was then beaten with sabers and bayonets and left for dead... allowing him to escape [ЦДАГОУ. Ф. 1. Оп. 18. Д. 16. Л. 93-93 об.]. When reading these accounts, one might think that such bravado better fits a spy or war novel than a narrative of class struggle.

\section{From Disillusionment to Policy Shift}

The social and political situation in Ukraine after the Red Army's retreat had an impact on the Bolsheviks' views and practices, as we can read in the intelligence reports written by the Party's envoys. As they considered themselves activists of "the party of the proletariat", we will concentrate mainly on the accounts they wrote about the most industrialized places, eastern Ukraine and the Donbass ${ }^{9}$, to see how their Marxist patterns of analysis could fit reality.

The envoys wrote captivating pieces of literature, not only when they relate their risky adventures, but also when they describe everyday life in White territory, as if they were explorers in some wild land or, more properly, time travelers in the pre-revolutionary past. Just after he had crossed the frontline, one first noticed "constables (zhandarmy) dressed as under the tsar". Then, peasants told him about the return of their landlords, backed by Cossacks. Further into the Donbass, he met "starved and ragged workers forced out of their houses to go to work by a bailiff (pristav) with a whip (nagayka) in his hands". This picture of brutal exploitation in the Donbass is confirmed by other Bolshevik envoys describing the "heavy situation (shooting, arrests, insufficient wages) " and workers trying to flee the region [ЦДАГОУ. Ф. 1. Оп. 18. Д. 20. Л. 2-2 об., 6; see also: Куромія, с. 158-159].

However, reports also describe some more disturbing facts for the Bolshevik doxa. Envoys agree in stating that markets were flourishing again after the Reds had gone: food products reappeared and prices fell [ЦДАГОУ. Ф. 1. Оп. 18. Д. 16. Л. 32 об., 38-39]. Although the drop in wages was

${ }^{7}$ About the ill treatment of Red Army prisoners, see [ЦДАГОУ. Ф. 1. Оп. 18. Д. 20. Л. 4; КП(б)У и Деникинщина, с. 29]. Concerning the Judicial Inquiry Commissions against "participants of the Bolshevik sedition", see: [ЦДАГОУ. Ф. 998. ОП. 1. Д. 1; Полтавская судебно-следовательная комиссия начальника гарнизона Добровольческой армии, 1919; Ф. 1012, Оп. 1. Д. 1, 2, 3, 4, 6. Харьковская судебно-следовательная комиссия, 1919]. About "punitive units" (karatel'nye otrjady) in the countryside, see reports by Bolshevik envoys: [ЦДАГОУ. Ф. 1. Оп. 18. Д. 16. Л. 34, 55 об.; Д. 20. Л. 2; Д. 33. Л. 3, 5]. For a discussion about White Terror, see: [Bortnevski; Цветков].

${ }^{8}$ She was Jewish.

${ }^{9}$ Including its Russian part around Rostov. 
cruelly felt, abundance had an impact on the workers' mood. Interviewed refugees from Kharkov who fled to the Reds reported that "great discontent against Denikin cannot be observed" and the local newspaper published “workers' resolutions backing Denikin” [ЦДАГОУ. Ф. 1. Оп. 18. Д. 5, Л. 9, 15]. Even though socialist parties were forbidden, trade unions still existed and gave shelter to leftist activists. Mensheviks headed them and dared to oppose the Whites' power by organizing (or being allowed to organize) strikes, although on a purely economic basis. [ЦДАГОУ. Ф. 1. Оп. 18. Д. 5. Л. 3, 6, 7; Ф. 1. Оп. 18. Д. 16. Л. 15, 32 об., 68; КП(б)У и Деникинщина, с. 29; КП(б)У за Денікінщини, 1929, с. 302, 311].

Menshevik leaders avoided raising the flag of revolution and respected the existing laws. In turn, "Denikin could play with urban democracy"10 $[К П(6) \mathrm{y}$ за Денікінщини, 1929, с. 310]. Menshevik leadership in the labor movement was not only based on the fact that they were less persecuted than the Bolsheviks. Envoys had to admit that this moderate policy suited the workers better. Reading some reports, communists might even think that Menshevism was a lesser evil in the political evolution of the Ukrainian working class. Railway workers were said to be on the Whites' side [ЦДАГОУ. Ф. 1. Оп. 18. Д. 16. Л. 32], which might have been the consequence of the conflict that sparked between the Bolsheviks and the Vikzhel, the railway workers' union, as early as October 1917 [see: Augustine; Rosenberg].

However, the workers' hostility toward Bolsheviks existed beyond the proletarian aristocracy of railway workers. The account of Afonin, a skilled worker and a revolutionary since 1905, is of particular interest. In 1917, he was working at the Gartman factory in Lugansk (Luhansk), a heavy steam-engine factory employing 5,000 workers. He was the secretary of a Bolshevik organization, was elected to the local soviet, and worked closely with Voroshilov. In early 1918, the factory was a Bolshevik stronghold, providing Red guards to fight against the Germans. Thus, Afonin became a Red soldier and fought at Tsaritsyn later that same year [Гражданская война, с. 140-141; Великий Жовтень, с. 45, 132]. He was in Kiev when the city fell into the hands of Denikin's troops in August 1919. After 150 Kievian Bolsheviks were arrested and shot, he headed to the Donbass and managed to get hired back at the Gartman factory. He proposed setting up a Bolshevik group to two colleagues: "They refused to work for the party cell, invoking the workers' anti-Soviet counter-revolutionary mood, which I had noticed; I saw how some comrades had been grabbed from their workbenches by White policemen and how some workers were pleased about it. $\langle\ldots\rangle$ Red Lugansk was red until conscious comrades retreated, but, under Denikin, Lugansk was bright white” [ЦДАГОУ. Ф. 1. Оп. 18. Д. 20. Л. 10].

Being uprooted from the toiling masses, Bolshevik underground groups could not rely on a web of sympathizers and were more vulnerable to re-

10 "Democracy" is used in the meaning coined in February 1917, as a synonym for socialist parties. 
pression. This explains the successive provaly (collapses) of illegal party and revolutionary committees in various cities. Organizational failures and the inability to influence the working class provoked bitter discussions and political reassessments in the underground. In Khar'kov, some recently dispatched activists stuck to the old party line, highlighting the need to strengthen party groups first, whereas locals stated that "along with organizational work, the military department must be instructed to help disorganize the enemy's rear by all means necessary" [КП(б)У и Деникинщина, c. 26]. This course toward the organization of sabotage and insurgent groups could not be implemented in Khar'kov, where most party committee members were soon arrested. However, in Lugansk after the failure of factory militancy, "people were sent to nearby environs... and it was soon possible to organize 18 villages and four mining communities, aiming at setting up groups of fighters rather than of party members" [ЦДАГОУ. Ф. 1. Оп. 18. Д. 16. Л. 16 об.]. Lugansk insurgents succeeded, for instance, in sabotaging the railway [ЦДАГОУ. Ф. 1. Оп. 18. Д. 20. Л. 12 об.]. Similarly, the party cell in Potok, a suburb of Kremenchug, decided to hinder the Whites' war effort "by means of terror", "despite the fact that a partisan group is contrary to the program of the party, but taking into account today's situation". Nonetheless, they would at least "try to form a purely communist group" [ЦДАГОУ. Ф. 1. Оп. 18. Д. 5. Л. 79-80].

In fact, although they thought they were straying from the Party's program, the Bolsheviks from Potok were sticking to the Party line, or at least to the line of some party bodies. Since the summer, the military department of the $\mathrm{CP}(\mathrm{b}) \mathrm{U}$ had been enforcing the establishment of partisan units in Denikin's rear. This was no easy task. The war-like reaction of the White forces was even more bloody than the repression in towns. Peasants were defiant towards commissars, Jews, and "the commune" and were thus more inclined to follow Petlyurists or Makhnovists than communists [ЦДАГОУ. Ф. 1. Оп. 18. Д. 5. Л. 20а-20б. Д. 16. Л. 13 об. Д. 20. Л. 8-9 об. Д. 42. Л. 5-6]. Still, the reports about Bolshevik leadership in peasant partisan units are impressive. Envoys with no local connections could become the commanders of spontaneous groups made up of left nationalists (borot'bysty) or socialists, even if they arrived straight from Moscow [ЦДАГОУ. Ф. 1. ОП. 18. Д. 42. Л. 7, 53, 62]. This means that whereas the urban working class was apathetic in the second half of 1919, the Ukrainian peasantry was rising once again, looking for cadres able to guide the insurgency. The Bolsheviks proved to have both the organizational and political skills for this.

The Zafrontbyuro and the communications department of the CP(b)U's CC called the activists sent behind enemy lines "agents", a term that activists themselves used [КП(б)У за Денікінщини, с. 264; ЦДАГОУ. Ф. 1. Оп. 18. Д. 16. Л. 62 об.; Ф. 1. Оп. 18. Д. 42. Л. 16-17]. It was an accurate word, as the activists were mostly involved in spying and setting up irreg- 
ular armed units. By doing so, they contributed to ousting Denikin from Ukraine. However, this was a sharp shift from their original class-oriented militancy. The CP and Red Army apparatuses exercised objective pressure in this direction. Subjectively, political reality proved to be different from their Marxist blueprint: "We are welcomed by peasants whereas workers are indifferent” [КП(б)У за Денікінщини, 1929, с. 310].

This forced the Bolsheviks to adapt not only their political practices but also their worldview, which had long-lasting consequences, beginning with the last days of 1919. Henceforth, the $\mathrm{CP}(\mathrm{b}) \mathrm{U}$ 's course sharply differed from that a year earlier. First, a new personnel policy was implemented by instruction of the $\mathrm{RCP}(\mathrm{b})$ in order to prevent "the inundation of Soviet institutions with elements of the Ukrainian urban petty bourgeoisie, devoid of understanding of the living conditions of the broad peasant masses and often cloaking themselves with the banner of communism". In plain words, this meant cutting off the flux of Jewish communists [Pavliuchenkov, p. 34]. Meanwhile, the radical and equalitarian agrarian policy of early 1919 was dropped in favor of "striving for reconciliation with the middle peasantry" [Раковский, с. 19; see: Aunoble, 2008, p. 178-184]. In turn, this peasant-friendly orientation also strengthened the Ukrainian national-communist current. An envoy in western Ukraine reported in late 1919 about the positive reception of Bolshevism in nationalist milieus [ЦДАГОУ. Ф. 1. Оп. 18. Д. 16. Л. 3-9 об., 50-50 об.; the report was published at the peak of the Ukrainisation policy: Попов, с. 43-50].

On the complex stage of Ukrainian society, the Bolsheviks now played a quite new role. "Proletarian revolutionaries" led armed peasants (as partisans or Red soldiers) to penetrate Ukrainian industrial cities just like conquerors invading foreign soil [Кульчицкий, т. 1, с. 414-415]. Although Ukrainian peasant support for the Reds would not outlast the winter of 1919-1920, the Bolsheviks' mistrust towards the mass of workers also became permanent. In December 1919, Zatonsky declared that Donbass miners' "proletarian consciousness, which was already low, is now completely crushed" [Quoted by Куромія, с. 172-173]. A Khar'kov activist would later remember that "at the first party meeting [after the liberation of the city], there were 300 people claiming to be communists and considering that hiding and not doing anything had been a great help for us" under Denikin [ДАХО. Ф. П10. Оп. 1. Д. 344. Л. 34]. Thus, the communist activists worked and lived more and more amongst themselves, just like the aristocracy they thought they were [Aunoble, 2015, p. 243-245].

Closed to the surrounding population, the communist elite was nonetheless far from united. The defiance of field activists toward the Party's apparatus, which sent them with improper credentials, and the way some ignored the leadership's directives was not forgotten in the Communist Party of Ukraine, which was always bitterly divided into competing factions. The publication of archival material recalling some people's failures easily became a weapon in internal squabbles, as footnotes explained that such and such had become oppositionists [КП(б)У за Денікінщини, 1929, с. 322-323]. 
Last but not least, peasant guerrilla warfare became a tool in the communist toolbox. The experience of Siberian [see: Pereira] and Ukrainian partisans was taught in the Soviet Union [Дробов, с. 110-160]. In 1936, the Komintern senior activist Walter (Tito) probably attended "courses in guerrilla warfare and espionage organized by the Cadres Department at the so-called 'Partisan Academy' in Riazan in reaction to the Spanish Civil War" [Pirjevec, p. 26]. During World War Two, Soviet and Yugoslavian communists would make partisan warfare a distinctive trait of communist struggle, and Chinese communists would soon control the most populous country on Earth by these means. Ukraine in 1919 was one of the first laboratories where this move from labor militancy to peasant insurgency was experimented with.

\section{Список литературы}

Великий Жовтень і громадянська війна на Україні : Енцикл. довід / відп. ред. І. Ф. Курас. Київ : Гол. ред. УРЕ, 1987. 630 с.

Гражданская война и военная интервенция в СССР : энциклопедия / гл. ред. С. С. Хромов. 2-е изд. М. : Сов. энцикл., 1987. 720 с.

ДАХО. Ф. П10. Оп. 1. Д. 344.

Дорошко М. Номенклатура: керівна верхівка Радянської України (1917-1938рр.). Київ : Ніка-Центр, 2008. 365 с.

Дробов М. А. Малая война: партизанство и диверсии. 1931. М. : Альм. «Вымпел», $1998.416 \mathrm{c}$.

КП(б)У за Денікінщини : [документи] // Летопись революции. 1929. № 5-6. C. $254-324$.

КП(б)У и Деникинщина - Из материалов Зафронтбюро // Летопись революции. 1925. № 1. C. 25-36.

Кульчиикий C. Червоний виклик : Історія комунізму в Україні від його народження до загибелі : в 3 т. Київ : Темпора, 2013. Т. 1. 503 с.

Куромія Г. Свобода і терор у Донбасі : Українсько-російське прикордоння, 18701990-і роки. Київ : Вид-во Соломії Павличко «Основи», 2002. 510 с.

КП(б)У за денікінщини : Місцеві підпільні парторганізації - київська та одеська : [документи] // Летопись революции. 1930. № 1. С. 221-241.

Майстренко I. Історія комуністичної партії України. Нью-Йорк : Сучасність, 1979. $259 \mathrm{c}$.

Мишкис X. КП(б)У за Денікінщини до документів // Летопись революции. 1929. № 5-6. C. 248-253.

Павлюченков C. «Орден меченосцев» : Партия и власть после революции. 19171928. М. : Собрание, 2008. 463 с.

Попов П. Петлюровское подполье на правобережной Украине - Путиществие в УНР (доклад в Зафронтбюро ЦК КП(б)) // Летопись революции. 1926. № 2. С. 31-50.

Раковский $X$. Отчет рабоче-крестьянского правительства Украины IV-му Bceукраинскому съезду советов рабочих, крестьянских и красноармейских депутатов 16-20 мая 1920 г. : с прил. резолюции Съезда и резолюций Центрального исполнительного комитета. Харьков : Всеукр. изд-во, 1920. 35 с.

Случевская С. Я. Деятельность Зафронтбюро ЦК КП(б)У (июль - декабрь 1919 года) : дис. канд. ист. наук. Киев : [Б. и.], 1966. 310, XXVIII с.

Фролов М. О. Компартійно-радянська еліта в УСРР (1917-1922 рр.) : Становлення і функціонування. Запоріжжя : Прем’єр, 2003. 448 с.

Хвильовий М. Із Варіної біографії [1928] // Хвильовий М. Новели, оповідання. Київ : Наукова думка, 1995. С. 389-410.

Цветков В. Ж. Репрессивное законодательство белых правительств // Вопр. истории. 2007. № 4. С. 16-26. 
ЦДАГОУ. Ф. 1. Оп. 18. Д. 5, 16, 20, 21, 40, 42, 47.

Abramson H. A Prayer for the Government: Ukrainians and Jews in Revolutionary Times, 1917-1920. Cambridge, Mass. : Harvard Univ. Press, 1999. 255 p.

Augustine W. R. Russia's Railwaymen, July - October 1917 // Slavic Rev. 1965. Vol. 24. № 4. P. 666-679.

Aunoble É. «Le communisme tout de suite ! », Le mouvement de communes en Ukraine soviétique 1919-1920. Paris : Les Nuits Rouges, 2008. 286 p.

Aunoble É. «Communistes, aux armes ! » : les unités à destination spéciale (TchON) au sortir de la guerre civile en Ukraine (1920-1924) // Hispania Nova. 2015. №13 / Amnis. 2015. № 14. P. 232-246. DOI 10.4000/amnis.2392.

Bortnevski $V$. White Administration and White Terror (the Denikin Period) // Russian Rev. 1993. № 3. P. 354-366. DOI 10.2307/130735.

Ferro M. Y a-t-il « trop de démocratie » en URSS ? // Annales. Économies, Sociétés, Civilisations. 1985. № 4. P. 811-827.

History of the Communist Party of the Soviet Union (Bolsheviks) : Short Course / ed. by Commission of the Central Committee of the CPSU(b). N. Y. : Intern. Publ., 1939. 364 p.

Hunczak T. The Ukraine, 1917-1921: A Study in Revolution. Cambridge, Mass. : Harvard Univ. Press, 1977. 424 p.

Pavliuchenkov S. The Jewish Question in the Russian Revolution, or Concerning the Reasons for the Bolsheviks' Defeat in the Ukraine in 1919 // Revolutionary Russia. 1997. № 10.2. P. 25-36. DOI 10.1080/09546549708575671.

Pereira N. G. O. The Partisan Movement in Western Siberia, 1918-1920// Jahrbücher für Geschichte Osteuropas. 1990. Neue Folge. Bd. 38. H. 1. P. 87-97.

Pirjevec J. Tito and His Comrades. Madison, Wisconsin : Univ. of Wisconsin Press, 2018. $535 \mathrm{p}$.

Rabinowitch A. Prelude to Revolution: The Petrograd Bolsheviks and the July 1917 Uprising. Bloomington; L. : Indiana Univ. Press, 1968. 229 p.

Rabinowitch A. The Bolsheviks Come to Power. Vol. 2: The Revolution of 1917 in Petrograd. N. Y. : W. W. Norton \& Co., 1976. XXXIII, 393 p.

Rabinowitch A. The Bolsheviks in Power: The First Year of Soviet Rule in Petrograd. Bloomington : Indiana Univ. Press, 2007. 495 p.

Rosenberg W. G. The Democratization of Russia's Railroads in 1917 // The Am. Historical Rev. 1981. Vol. 86. № 5. P. 983-1008.

Ulam A. The Bolsheviks: The Intellectual and Political History of the Origins of the Triumph of Communism in Russia. N. Y. : Macmillan ; L. : Collier-Macmillan, 1965. IX, $598 \mathrm{p}$.

\section{References}

Abramson, H. (1999). A Prayer for the Government: Ukrainians and Jews in Revolutionary Times, 1917-1920. Cambridge, Mass., Harvard Univ. Press. 255 p.

Augustine, W. R. (1965). Russia's Railwaymen, July - October 1917. In Slavic Rev. Vol. 24. No. 4, pp. 666-679.

Aunoble, É. (2008). "Le communisme tout de suite!", Le mouvement de communes en Ukraine soviétique 1919-1920. Paris, Les Nuits Rouges. 286 p.

Aunoble, É. (2015). "Communistes, aux armes!" : les unités à destination spéciale (TchON) au sortir de la guerre civile en Ukraine (1920-1924). In Hispania Nova. No. 13 / Amnis. No. 14, pp. 232-246. DOI 10.4000/amnis.2392.

Bortnevski, V. (1993). White Administration and White Terror (the Denikin Period). In Russian Rev. No. 3, pp. 354-366. DOI 10.2307/130735.

Commission of the Central Committee of the CPSU(b). (Eds.). (1939). History of the Communist Party of the Soviet Union (Bolsheviks). Short Course. N. Y., Intern. Publ. 364 p. 
$D A K h O$ [State Archive of the Kharkiv Region]. Stock P10. List 1. Dos. 344.

Doroshko, M. (2008) Nomenklatura: kerivna verkhivka Radyans'koï Ukraïni (19171938 rr.) [Nomenklatura: The Top Leadership of Soviet Ukraine (1917-1938)]. Kiïv, NikaTsentr. 365 p.

Drobov, M. A. (1998). Malaya voina: partizanstvo i diversii. 1931 [The Little War: Resistance Movement and Subversion. 1931]. Moscow, Al'manakh "Vympel". 416 p.

Ferro, M. (1985). Y a-t-il "trop de démocratie" en URSS? In Annales. Économies, Sociétés, Civilisations. No. 4, pp. 811-827.

Frolov, M. O. (2003). Kompartiino-radyans'ka elita v USRR (1917-1922 rr.). Stanovlennya i funktsionuvannya [The Communist-Soviet Elite in Soviet Ukraine (19171922). Establishment and Functioning]. Zaporizhzhya, Prem'yer. 448 p.

Hunczak, T. (1977). The Ukraine, 1917-1921: A Study in Revolution. Cambridge, Mass., Harvard Univ. Press. 424 p.

Khromov, S. S. (Ed). (1987). Grazhdanskaya voina i voennaya interventsiya $v$ SSSR. Entsiklopediya [The Civil War and the Military Intervention in the USSR. Encyclopaedia], $2^{\text {nd }}$ Ed. Moscow, Sovetskaya entsiklopediya. 720 p.

Khvil'ovii, M. (1995). Iz Varinoï biografiï [From Varvara's Biography]. In Khvil'ovii, M. Noveli, opovidannya. Kiïv, Naukova dumka, pp. 389-410.

$\mathrm{KP}(\mathrm{b}) \mathrm{U}$ i Denikinshchina - Iz materialov Zafrontbyuro [The CP(b)U and Denikin's Rule - From the Materials of the Zafrontbyuro]. (1925). In Letopis' revolyutsii. No. 1, pp. 25-36.

$\mathrm{KP}(\mathrm{b}) \mathrm{U}$ za Denikinshchini. Dokumenti [The CP(b)U under Denikin. Documents]. (1929). In Letopis' revolyutsii. No. 5-6, pp. 254-324.

Kul'chitskii, S. (2013). Chervonii viklik. Istoriya komunizmu v Ukrä̈ni vid iogo narodzhennya do zagibeli $v 3 t$. [The Red Challenge. The History of Communism in Ukraine from Birth to Death. 3 Vols.]. Kiïv, Tempora. Vol. 1. 503 p.

Kuras, I. F (Ed). (1987). Velikii Zhovten' $i$ gromadyans'ka viina na Ukrä̈ni. Entsiklopedichnii dovid [Great October and the Civil War in Ukraine. An Encyclopaedic Reference Book]. Kiïv, Golovna redaktsiya Ukraïns'koï radyans'koï entsiklopediï. 630 p.

Kuromiya, G. (2002). Svoboda i teror u Donbasi: Ukraïns'ko-rosiis'ke prikordonnya 1870-1990-i roki [Freedom and Terror in the Donbass: The Ukrainian-Russian Borderland, 1870-1990s]. Kiïv, Vidavnitstvo Solomiï Pavlichko “Osnovi”. 510 p.

$\mathrm{KP}(\mathrm{b}) \mathrm{U}$ za Denikinshchini. Mistsevi pidpil'ni partorganizatsiï - kiïvs'ka ta odes'ka. Dokumenti [The CP(b)U under Denikin. Local underground Party organizations in Kyiv and Odesa]. Documents (1930). In Letopis'revolyutsii. No. 1, pp. 221-241. [Annals of the Revolution]. (1930). No. 1.

Maistrenko, I. (1979). Istoriya komunistichnoï partiï Ukraïni [History of the Communist Party of Ukraine]. N. Y., Suchasnist'. 259 p.

Mishkis, Kh. (1929). KP(b)U za Denikinshchini do dokumentiv [The CP(b)U under Denikin - Foreword to Documents]. In Letopis' revolyutsii. No. 5-6, pp. 248-253.

Pavliuchenkov, S. (1997). The Jewish Question in the Russian Revolution, or Concerning the Reasons for the Bolsheviks' Defeat in the Ukraine in 1919. In Revolutionary Russia. No. 10.2, pp. 25-36. DOI 10.1080/09546549708575671.

Pavliuchenkov, S. (2008). "Orden mechenostsev". Partiya i vlast' posle revolyutsii. 1917-1928 [The "Brotherhood of the Sword". The Party and Power after the Revolution. 1917-1928]. Moscow, Sobranie. 463 p.

Pereira, N. G. O. (1990). The Partisan Movement in Western Siberia, 1918-1920. In Jahrbücher für Geschichte Osteuropas. Neue Folge. Bd. 38. H. 1, pp. 87-97.

Pirjevec, J. (2018). Tito and His Comrades. Madison, Wisconsin, Univ. of Wisconsin Press. 535 p.

Popov, P. (1926). Petlyurovskoe podpol'e na pravoberezhnoi Ukraine - Putishchestvie v UNR (doklad v Zafrontbyuro TsK KP(b)) [The Petlyurist Underground in Right-Bank Ukraine - A Journey in the Ukrainian People's Republic (Report to the Zafrontbyro)]. In Letopis'revolyutsii. No. 2, pp. 31-50. 
Rabinowitch, A. (1968). Prelude to Revolution: The Petrograd Bolsheviks and the July 1917 Uprising. Bloomington, L., Indiana Univ. Press. 229 p.

Rabinowitch, A. (1976). The Bolsheviks Come to Power. Vol. 2: The Revolution of 1917 in Petrograd. N. Y., W. W. Norton \& Co. XXXIII, 393 p.

Rabinowitch, A. (2007). The Bolsheviks in Power: The First Year of Soviet Rule in Petrograd. Bloomington, Indiana Univ. Press. 495 p.

Rakovskii, Kh. (1920). Otchet raboche-krest'yanskogo pravitel'stva Ukrainy IV-mu Vseukrainskomu s"ezdu sovetov rabochikh, krest'yanskikh i krasnoarmeiskikh deputatov 16-20 maya $1920 \mathrm{~g}$. S prilozheniem rezolyutsii $S$ "ezda i rezolyutsii Tsentral'nogo ispolnitel'nogo komiteta [Report of the Workers' and Peasants' Government... 16-20 May 1920]. Kharkov, Vseukrainskoe izdatel'stvo. 35 p.

Rosenberg, W. G. (1981). The Democratization of Russia's Railroads in 1917. In The Am. Historical Rev. Vol. 86. No. 5, pp. 983-1008.

Sluchevskaya, S. Ya. (1966). Deyatel'nost'Zafrontbyuro TsK KP(b)U (iyul'-dekabr' 1919 goda) [The Activities of the Zafrontbyuro by the CC of the CP(b)U]. Avtoref. dis.... kand. ist. nauk. Kiïv, S. n. 310, XXVIII p.

TsDAGOU [Central State Archive of the Public Associations of Ukraine]. Stock 1. List 18. Dos. 5, 16, 20, 21, 40, 42, 47.

Tsvetkov, V. Zh. (2007). Repressivnoe zakonodatel'stvo belykh pravitel'stv [The Repressive Laws of the White Governments]. In Voprosy istorii. No. 4, pp. 16-26.

Ulam, A. (1965). The Bolsheviks: The Intellectual and Political History of the Origins of the Triumph of Communism in Russia. N. Y., Macmillan, L., Collier-Macmillan. IX, 598 p.

The article was submitted on 11.06.2020 